\title{
The Implementation of Child Livelihood Payment after Divorce Occurs in the Perspective of the Shafi' School of Fiqh and Positive Law (Post-Court Judgment Analysis Study in North Sumatra)
}

\author{
Asmuni $^{1}$, Pagar Hasibuan ${ }^{2}$, Ahmad Zuhri Rangkuti ${ }^{3}$ \\ ${ }_{1,2,3}$ Universitas Islam Negeri Sumatera Utara, Indonesia \\ zuhriray82@gmail.com,asmuni@uinsu.id.ac,prof.pagar@yahoo.com
}

\section{Abstract}

As many as $80 \%$ of the judges' verdicts at the North Sumatra Religious Court (PA Sumut) were ignored by their former husbands, excluding education and health costs. This study aims: (1) to find out how to pay for children's livelihoods after divorce, from the perspective of the Syâfi $i$ school of jurisprudence, (2) to find out how to pay for child support after divorce, with a positive legal perspective (3) to find out how to determine children's livelihoods after divorce from the perspective of the fiqh school of thought Shafi $i$ PA North Sumatra. This research uses field research methods by collecting primary data with direct interview respondents, direct observation in North Sumatra PA, collecting closely related data and information, supported by library research methods. This type of research is field research. This research approach is sociological juridical. The nature of the research is descriptive-analysis. The data sources were obtained from primary, secondary and tertiary legal materials. Data collection methods by means of interviews and documentation. Research conclusions: (1) how to pay for child support after

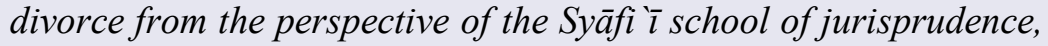
namely a) asking or taking the method directly according to the local urf, b) giving it directly by the ex-husband or through a representative according to the local urf, c) filing a lawsuit. (2) The method of paying for children's livelihoods after divorce from a positive legal perspective, namely: a), handing over directly to the mother, $b$ ) the Court's decision due to divorce or sue (3) The way North Sumatra PA determines children's livelihoods after divorce, namely through: a) the child's mother, b) a verdict, c) filing a lawsuit.
Keywords

child livelihood, divorce, fiqh; positive law, Religious Court

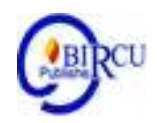

\section{Introduction}

Getting married is one phase of life that is commonly done by every adult human, ready physically and mentally, and has a sense of responsibility in building a household. Every person who has fulfilled these requirements is recommended to set his feet to the level of marriage. It is this level that marks a phase of life that is very important for one's survival in the future. Compared to living alone, family life has many challenges and also contains a number of positive expectations. No doubt in marriage there are many benefits if you can manage it well. (Surya et al, 2019) 
The family has a very big role in teaching, guiding, determining behavior, and forming a perspective on the values that apply in society. The family is like giving the values that are needed by the child through an appropriate communication pattern so that communication goes well, harmonious relationships are created, and the messages and values to be conveyed can be accepted and practiced properly. (Batubara, 2019)

The divorce rate in North Sumatra is very sharp, in 2017 the Medan Religious Court tried $80 \%$ of divorce cases. The main cause that triggers it is a lack of understanding between partners about their respective responsibilities in the household. Until February 2019 divorce cases that occurred in Medan had reached 308 divorce cases experienced by young couples. Of the 308 divorce cases, 28 cases ended in peace. The factors that dominate the occurrence of divorce in young couples in the city of Medan, North Sumatra include the economy and drug use. The result of divorce for old or elderly spouses is a moral crisis in one of the spouses which results in being irresponsible for the family, looking for another spouse and economic factors because the husband does not provide a living in the household.

Table 1. Divorce Cases

\begin{tabular}{|c|c|c|c|}
\hline No. & $\begin{array}{l}\text { Respodent } \\
\text { (Pseudonym) }\end{array}$ & No. Decision & $\begin{array}{c}\text { Post-Divorce Child Support: } \\
\text { Paid }(\sqrt{ }) \text { No }(X)\end{array}$ \\
\hline 1 & Zita & $\begin{array}{l}0941 \text { / AC / } 2013 \text { / } \\
\text { PA / MSy.Lpk. }\end{array}$ & $\mathrm{X}$ \\
\hline 2. & Rischa & $\begin{array}{l}1305 \text { / Pdt.G / } 2013 \text { / } \\
\text { PA.Mdn. }\end{array}$ & $\mathrm{X}$ \\
\hline 3. & Wanda & $\begin{array}{l}\text { 0245 / Pdt. G / } \\
\text { 2017PA. Lpk. }\end{array}$ & $\mathrm{X}$ \\
\hline 4. & Adelia & $\begin{array}{l}1121 \text { / Pdt. G / } 2016 \text { / } \\
\text { PA. Mdn. }\end{array}$ & $\mathrm{X}$ \\
\hline 5. & Nurdin & 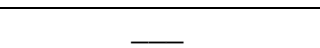 & $\sqrt{ }$ \\
\hline
\end{tabular}

Of the 5 divorce cases, 4 cases of ex-husbands did not pay for child support after the divorce, so the percentage was $4: 5 \times 100=80 \%$, so as many as $80 \%$ of the judges' decisions of PA North Sumatra were ignored by their ex-husbands, excluding education costs. And health if children's livelihoods are neglected and neglected, of course the livelihoods for education and health are neglected. This is because even though the North Sumatra PA decision decides the obligation to pay for children's livelihoods after a divorce and is in accordance with the Marriage Law, KHI, and Fiqh, the implementation of payment for living after a divorce is not as decided. The results of the researchers 'interviews with the respondents as a sample concluded that the respondents' ex-husbands did not want to fulfill their children's livelihoods after the divorce. The causes are quite diverse.

\section{Review of Literatures}

\subsection{According to the Shafi'i School}

According to Imām ash-Shāfi' ${ }^{1}$ (150-204 H / 767-819 AD), in the event of a divorce between husband and wife, the ex-husband is obliged to pay for his child. This is confirmed in Al-Umm:

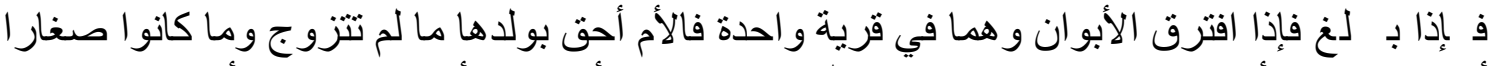

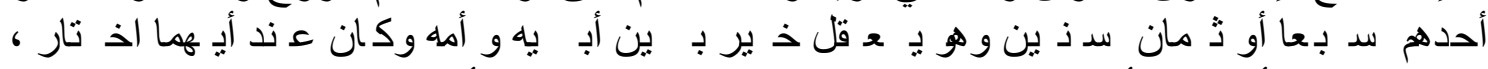

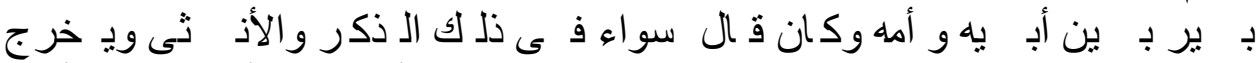

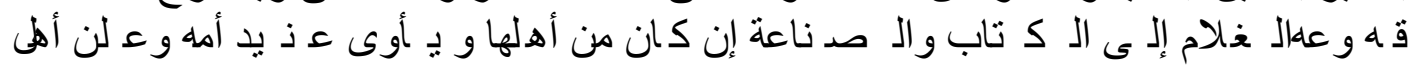


According to Asy-Shafi'i, if the two parents are separated and both are in one area, the mother has more rights to the child as long as she has not married someone else and the child is still small. When the child reaches the age of seven or eight and he is able to think, he is asked to choose between father and mother. Then he lives with whom he chooses. If the child chooses the mother, then the father must provide for him and he is not prevented from educating the child. In this case, the rights are equal between men and women. The child can go out to do his activities but the place to stay is the mother, while the father is still obliged to support him. As for when the child chooses the father, then the father has no right to prohibit the child from being visited by the mother nor may he forbid the child to come to the mother's place for a few days. "Thus, even though child care is in the hands of the mother, the child's responsibility is still borne by the responsibility of the father.

Ash-Shafi ' 1 does not reject the opinion that a husband is obliged to provide for his wife when it is dukhūl bihā, and if it turns out that the husband is away from his wife, it is obligatory for the government (sultān), in the current context the authority here is the Court. , decides the penalty for the husband's obligation to provide such a living from the husband's assets if a lawsuit is filed on the wife's side. If it turns out that the husband does not have money, the court (sulțān) makes him a debt.

\subsection{Positive Legal Perspective}

Regarding the way of providing child support after divorce according to Article 41 of the Law of the Republic of Indonesia Number 1 of 1974 concerning Marriage, is by means of a decision issued by the Court. The article states that:

1) Both the mother or the father are still obliged to care for and educate their children, solely on the basis of the child's interests, if there is a dispute regarding the child, the Court gives the decision.

2) The father is responsible for all the maintenance and education costs required by the child, if in fact the father cannot fulfill these obligations, the Court may determine that the mother is responsible for the costs.

3) The court can oblige the ex-husband to provide living expenses and / or determine an obligation for the ex-wife.

Meanwhile, according to the Compilation of Islamic Law, provision of child support after divorce is by: (1) Providing support for the child through the child's mother because the cost of caring for the child is borne by the father as in Article 105. (2) Court Ruling; as in Article 156 (a), (b), (d) and Article 149 (d). (3) Submitting a lawsuit.

Providing support for the child after the divorce occurs by handing over an amount of money directly through the child's mother, because the cost of caring for the child is borne by the father as in Article 105 .

Article 105 in the event of a divorce:

a. It is the mother's right to care for children who are not yet mumayyiz or not yet 12 years old.

b. Child care that is already mumayyiz is left to the child to choose between his father or mother as the holder of the right to care for him.

c. Maintenance costs borne by his father.

The provisions of the KHI, it appears that the responsibility of a father to his child cannot be canceled even though he has divorced his wife or he has remarried. It can also be understood that when the child is still young (not yet mature), its maintenance is the mother's right, but the costs are borne by the father. In addition, for children who are not yet mumayyiz, mothers get top priority to care for their children. If the child is mumayyiz, the child has the right to choose between the father and mother he follows. Depending on the child in determining the choice. 


\section{Research Methods}

Moving on from this type of research is field research (field research), so in conducting this research, the authors use field research methods. This method is done by collecting primary data with interview techniques (interview), in which researchers conduct direct interviews with respondents. The interview that the author did, of course, was by dealing directly with the interviewee. Respondents in question are persons who have litigation, former husbands and wives, and judges chosen by the authors in this study. And the authors made observations in which the authors made direct observations in PA North Sumatra and collected data and information that is closely related to this research with North Sumatra PA Judges. With this method too, the author asked several questions to 4 widows and 1 widower who had been divorced based on the decision of PA North Sumatra. This interview was conducted to obtain concrete information about whether the ex-husband paid for the child's support after the divorce and how the ex-husband paid for children's rights after the divorce and what the wife did to the ex-husband who did not fulfill his obligations. Along with the policies carried out by the PA in dealing with child support payments after the divorce occurred. This method is done by looking for data about things or variables in the form of notes, books, archives and documents. In this study, the annual archive for the recapitulation of divorce data from the people of North Sumatra was used. annual archive of recapitulation of North Sumatra community divorce data and copies of divorce decisions in North Sumatra PA. In this method or technique the researcher collects data from literature from the main book of the Shāfi' $\overline{1}$ school including Mausū'ah al-Imām asy-Shāfì'̄, al-Um, al-Muhażżab, Mugini al-Muhtāj, and references to the Shāfi` school. $\overline{1}$ and others.

\section{Result and Discussion}

In determining the child's income, which is decided by the father of the child, the judges of the North Sumatra Religious Court (Medan, Binjai and Stabat) will consider the income of the ex-husband and look at how the law says it. Thus the judge only combines all of these considerations. So from the judges themselves there are no problems or constraints in determining children's support. Because only based on these considerations, and carry out then decide. However, back to the problem arises when we have to execute it. We can only arrive at that first month. Even more sad, or the man does not pay for the child support. As in the procedure that the payment limit until after being called for 6 months. After 6 months to report back.

In this case, the person concerned is not given a pledge for divorce. The party can be given permission to make a pledge once it has the money and then report it to the Religious Court. Only then did the judge issue a divorce vow. In other conditions, if the husband does not heed these rules, he still does not want to pay, because in some cases there are also those who insist that they do not want to pay even though the time that has been given has expired, which is 6 months, then automatically the law has no power. . Those who litigate before the law, have their status back to being husband and wife, and this condition of course makes women adjourn, not supported.

Fuad Helmi emphasized that the child was forced to pay in the first month alone, although in the judge's decision, it was decided until the child was 21 years old. As for the following month, if it is not paid, then there is an element of crime because it constitutes child neglect. In other words, he (the ex-husband) did not heed the ruling of the Religious Court which was passed on to him. So this situation enters into a criminal, neglect case. So that if you have been sentenced, the trial will go to the District Court. As an example of a 
criminal case in Kisaran, the reason was that she did not pay her income, so the ex-wife finally reported it to the police. After the report was written down, the husband was called, because the husband was finally scared so he was willing to pay half of the demands, the amount to be paid was around Rp. 30,000,000, - (thirty million rupiah). So the ex-husband paid several million and the rest in installments. Thus, what the Religious Courts are pursuing must be paid only for the support of the first month's children. As for the following months, only the ex-husband's moral obligations to his ex-wife.

The practice that occurs in the Religious Courts remains like that, except for the criminal element, so it is brought to the criminal realm. Whoever filed. For example, the iddah income has been decided and then the pledge is read, then the head judge will file an obligation for one month in advance. As for the following month, the ex-husband will pay immediately, so when he is not paid in full, the wife can file a lawsuit against the ruling. Thus this case was brought to the District Court. As well as filing for divorce against the husband, the husband comes to attend the trial in court. In the lawsuit, the case was clearly explained, and the case was seated. This is when the husband comes, so there is an argument and so on, but in this field, the husband rarely comes.

From these problems, the question that arises is why do women ask for divorce? So the answer to this question is because the person concerned wants to end his household life, because he is no longer able to maintain his household life. But the divorce factor like this is not the case, only one or two cases. Among other things, such as divorce due to the fact that her husband is a man related to drug problems, her husband is using drugs, or because of domestic violence, her husband hit. It is clear that the woman is suing for divorce, because she is no longer able to maintain the conditions of the household. But he couldn't get his due. So here lies the weak position of women. Among them are those who have been hurt, beaten, kicked out, they just asked for a divorce.

If the case is divorce in child care, then the wife still gets the rights, if the child is not yet mature. Whereas in the matter of child support, if the husband never comes to fulfill the summons properly, then the execution of the child support is not impossible, but it will be empty because it is useless because it cannot be executed. So in the trial the judge will ask the woman why her husband did not come, where is he. So that the court will provide input to him. In the case of child support, even if the judge determines it is the same, it will be in vain. So that is the weak position of women in their practice in the field. It's different if the husband asks for divorce, of course the person concerned will come, and so usually the woman will come. So in conditions like this there is an opportunity to be discussed. If the husband does not want to pay a living, there is an opportunity for the court to force him to pay.

In practice, after completing the utterance of the husband's divorce vows against his exwife, the Religious Court does not have any right to force the ex-husband. Because there is no judge's authority in this matter. As for the legal solution, if she does not want to carry out the obligation to pay for children's livelihoods as the judge has decided, the woman may file a lawsuit at the District Court. Because this is neglect or does not heed the verdict. Thus this is no longer the authority of the Religious Courts, because judges at the Religious Courts, if they have given a decision and have legal force and it is legal, then it must be implemented. Therefore, it is the authorities who are able to force it, by way of a party demanding child support reporting it to the police stating that their opponent has neglected their obligations.

As for the authority of the Religious Courts in order to ensure that the father of the child carries out the obligation to pay for his child after the divorce, according to Helmawati this is a deleterious issue. But what is certain is that the judge has only reached the stage of ensuring payment in the first month. Because in that first month, the man still needed a 
Religious Court to submit a pledge for divorce. At the time of pronouncing the pledge of divorce, the court through the judge forced to pay in advance its obligations to the rights of women 'iddah, mut ah, and including child support, including that we will be forced. Why is it stated in the sentence the judge will insist, because in some cases many husbands argue that they do not have money but want to pronounce the pledge of divorce, then if the pledge has occurred, in the end the income is not paid. So that the woman who wanted to apply for execution collided, because the amount of money being chased was not large, while the cost of execution was greater. Due to the execution there are costs involved. So it is no longer possible for the Court to execute, it seems as if the judge's decision was in vain. So in order to be accommodated, it is given to those who have the right, by means of before the husband pronounces a divorce vow or when he is going to make a divorce vow, the judge orders to pay the obligations first, including child support after the divorce occurs. So it is no longer possible for the Court to execute, it seems as if the judge's decision was in vain. So in order to be accommodated, it is given to those who have the right, by means of before the husband pronounces a divorce vow or when he is going to make a divorce vow, the judge orders to pay the obligations first, including child support after the divorce occurs. So it is no longer possible for the Court to execute, it seems as if the judge's decision was in vain. So in order to be accommodated, it is given to those who have the right, by means of before the husband pronounces a divorce vow or when he is going to make a divorce vow, the judge orders to pay the obligations in advance, including child support after the divorce occurs.

Thus, after completing the pledge of divorce, the Court does not have any right to force the person concerned again. Because there is no judge authority. The chance is that if the husband still doesn't want to pay his obligations, then the wife may file a lawsuit at the District Court. In this case, it is an act of neglect or disregard for the decision. If it has been delegated to the District Court, then this is no longer the authority of the Religious Courts, because if the Religious Courts have given a decision and it is legally binding, then it must be implemented, then the party that can force it is the police. The women must report to the police, in cases of negligence.

As for the explanation regarding the payment of living before pronouncing the talak vow, it can be seen from the steps in the payment as follows: First, filing a case to be registered at the Religious Court. Second, the court establishes a panel of judges and a substitute clerk formed by the head of the court. Third, the determination of the trial date determined by the chairman of the panel of judges. Fourth, the bailiff calls the parties before the three-day trial begins. Fifth, the trial started from the opening of the trial based on a predetermined time, then asked the identity of the parties, suggested mediation. Sixth, if the mediation is not successful, then proceed with reading the lawsuit and then answering the lawsuit. Seventh, duplicate replication, then proof, after the proof, namely the conclusions of the parties. Eighth, the judge consults and reads the verdict. Ninth, after being legally binding, the parties are then recalled to carry out the divorce pledge. So before pronouncing the divorce vow, a husband is ordered to pay for the wife's rights in the form of iddah and mut ah livelihoods. Tenth, after payment is carried out the recitation of the divorce vow. If the husband does not have money, the pledge of divorce will be postponed and it will be carried out if the husband already has the money and the time given is a maximum of 6 months, and if six months have not been able to pay the living to the wife, it is considered null and void to carry out the divorce. So before pronouncing the pledge of divorce, a husband is ordered to pay for the wife's rights in the form of 'iddah and mut ah livelihoods. Tenth, after payment is carried out the recitation of the divorce vow. If the husband does not have money, the pledge of divorce will be postponed and it will be carried out if the husband already has the money and the time given is a maximum of 6 months, and if six months have 
not been able to pay the living to the wife, it is considered null and void to carry out the divorce. So before pronouncing the divorce vow, a husband is ordered to pay for the wife's rights in the form of 'iddah and mut ah livelihoods. Tenth, after payment is carried out the recitation of the divorce vow. If the husband does not have money, the pledge of divorce will be postponed and it will be carried out if the husband already has the money and the time given is a maximum of 6 months, and if six months have not been able to pay the living to the wife, it is considered null and void to carry out the divorce.

Based on the theory of maqashid syarīah, including hifẓu nafsi and hifẓu nasl. In this case, safeguarding the soul (nafsi) of the child after a divorce between the two parents has the meaning of protecting oneself from things that are harmful (damage) that will lead to someone's extinction. The concept of guarding the soul is very relevant in providing protection for children because it is in accordance with the Child Protection Law. His juridical approach is based on the word of Allah SWT: "Who makes death and life, so that He will test you, which one of you is better at doing. And He is Mighty, Most Forgiving." (Surah Al.-Mulk [67]: 2).

In line with that, the 1945 Constitution as the state constitution, Article $28 \mathrm{~A}$, states that "Everyone has the right to live and has the right to defend his life and life." The philosophical approach is that guarding the soul is not only limited to the concept of freedom of life (hurriyah al-hayât), someone is protected by the state to obtain a safe, prosperous and peaceful life. Every soul of a person who is an Indonesian citizen, the right to life must be protected whether he is an adult or a child so that the expected civil society will be created. The loss of life or acts of neglect of a child after a divorce, or not paying for the child's support after the divorce is a form of harm to humanity itself.

Costs outside the child's income included in the decision, apart from children's support, are health and education costs. Among the income earning education, the most important is religious education income. Because the presence of children in a family has many meanings, not only as a successor to the inheritance and fruit of the love of a married couple, but also as a symbol of civilization from one family and the previous generation. Also as a symbol of a family or generation, which of course also attaches a hope to maintain the existence and survival of children with all their success in life. According to Ahmad Tafsir, an education expert, that every parent would want his child to be a person who develops perfectly. They want the children born to be healthy, strong, and skilled, intelligent, clever, and have faith. In a simple level, parents do not want their children to be weak, sickly, unemployed, stupid, and naughty. At the simplest level, parents do not want their children to be naughty and become unemployed. Finally, at the very minimum level is not to be naughty. Mischief will cause the parents shame and trouble.

Normatively, Islam has given a warning that the greatest concern is when parents leave the next generation in a weak state. Of course we are weak in various things, especially weak in faith, weak in knowledge and lack of life skills, and so on. This means that parents must see their children as a hope for the future. In the Qur'an there are two verses in different surahs which remind us to pay great attention to the future generation of the ummah in general, and the future of the children as the next generation. In many verses this shows, including: QS Al-Hasyr (59) verse 18: "The day of those who believe, fear Allah and let each one pay attention to what he has done for the next day (hereafter), and fear Allah, verily Allah knows best what you are doing. " And QS An-Nisā '(4) verse 9: "And fear Allah those who should leave behind them weak children, whom they worry about (their welfare). Therefore, let them fear Allah and let them speak the right word. "

Children who come from broken homes, victims of divorce from their parents, children who live in troubled family conditions like this have resulted in some children being 
neglected. Even though living under the care of their parents (mother) or relatives, it is not a guarantee that the continuity and efforts to fulfill their rights as children are truly guaranteed, especially for those with low economic levels. For neglected children, what they really need is not just getting protection and fulfilling their basic needs, but what is equally important is how they can get assurance and the opportunity to grow and develop naturally. Even though many community members will sympathize and care for the advice of neglected children,

In terms of physical appearance, the treatment and threats faced by abandoned children may not be as dramatic as children who are victims of violence, such as girls who are victims of rape or children who are victims of violence being physically injured, or even persecuted to death. However, from a social and psychological perspective, the threats faced by abandoned children are no less dangerous. At the individual level, children are used to being neglected from an early age, usually they grow inferior, have low self-esteem, or otherwise become aggressive and naughty to attract the attention of those around them. In fact, it is not impossible for abandoned children to become involved in criminal acts due to misconduct and association.

Indeed, it is not always that families with psychological problems or families who live under the pressure of poverty will always neglect their children. However, for families who live barely everyday life, have just been laid off, are wracked with ever-increasing debt, and this does not rule out the possibility that mothers of children who provide for their children after a divorce will experience it, so not only will they experience it. easily irritable and prone to stress, but also prone to do wrong things to their children. A child who is born in a family with economic problems, it is not impossible that their future will be neglected, and may even become the object of violence. The results of Ana Latifatul Mutamah's research reveal that economic factors are the first factors that cause people to marry off their underage children. This happens to the child's parents who are no longer able to support their child, then take the decision to marry off their child to someone who is considered more capable. This also causes the education level of women to be low, because they prefer to get married rather than continue their education, because even if they want to go to school, their parents do not have sufficient funds to send them to school.

\section{Conclusion}

The way of paying for child support after a divorce, according to the theory of the Shāfi ' $\overline{1}$ school of thought, is as follows: a) Requesting or taking directly in accordance with the local 'urf. Must be adapted to the 'urf, tradition or local customs with a measure known in the customs, local customs, b) submitted directly by the ex-husband or through a representative in accordance with the local urf, c) filing a lawsuit. According to positive law: a) submit directly to the mother, b) the Court's decision due to divorce or sue divorce. (3) The Religious Courts in North Sumatra (Medan, Binjai and Stabat) determine the method of payment for child support after divorce, namely through: a) the child's mother, b) a verdict, c) filing a lawsuit. 


\section{References}

Asy-Syāfi'ì. (2009). Habrul Ummah wa Imām al-Aimmah al-Imām Abū 'Abdullāh Muḥammad Al-Imām Abū `Abdullāh in Muḥammad bin Idrīs. Al-Um. Bāirūt: Dār alFikr, jilid II, cet. 1 .

.(2009). Abū `Abdullāh Muḥammad Al-Imām Abū `Abdullāh in Muḥammad bin Idrīs. Al-Um. Bāirūt: Dār al-Fikr, jilid III, cet. 1 .

Abū al-Ḥasan. (1994) Ali bin Muhammad bin Habīb al-Māwardī al-Bașarī, Al-Ḥāwī alKabīru fì Fiqhi Mażhab al-Imām asy-Syāfì '̄ wa Huwa Syarḥ Mukhtashar al-Muzani, ditahqīq oleh Syaikh `Ali Muḥammad Mu`awwạ̣ dan Syaikh `Adil Aḥmad Abdul Maujūd. Lebanon: Dār al-Kutub al-'Ilmiyyah, jilid XI.

'Ayyāḍ. (1979). As-Sayyid Șāliḥ. Aśaru al- 'Urf fī at-Tasyrī' al-Islāmī. Kairo: Dār al-Kitāb alJāmi`̄i.

As-Sijistāni. (2009). Imām al-Ḥāfiz Abī Dāud Sulaimān bin al-Asy`as̀ al-Azadi. Sunan Ab̄̄ Dāwud, taqīq dan takhrīj hadis oleh Syu aib al-Arnuṭ, et. al. Bairūt: Dār ar-Risālah alĀlamiyyah, cet. I, Jilid. III.

Asy-Syīrāzī. (2014). Abū Ishāa Ibrāhīm `Ali bin Yūsuf al-Fairūz Abādī. Al-Muhażżab fi Fiqhi al-Imām asy-Syāfi' ’̀. Kairo: Ad-Dārul `Ālamiyyah li an-Nasyr wa at-Tauz̄̄’, cet. I.

As-Sirjāni, Rāgib. (2010). Ruhamā’ Bainahum: Qișșah at-Takāful wa al-Ig̣āsah fĩ al-Ḥaḍārah al-Islāmiyyah. Giza-Mesir: Nahḍah Misr, cet. I.

Ahmad, La Ode Ismail. (2014). "Hadis Tentang Hak Nafkah Bagi Wanita yang Ditalak Tiga: Kasus Fāṭimah binti Qais,” dalam Jurnal Al-Maiyah. Vol. 7 No. 1 Januari.

Arikunto, Suharisimi.(1993) Prosedur Penelitian: Suatu Pendekatan Praktik (Jakarta: Rineka Cipta.

Ali, Zainuddin. (2006). Hukum Perdata Islam di Indonesia. Jakarta: Sinar Grafika, cet. I.

Ayuningtyas, Sekar.(2016). Manajemen Permasalahan Rumah Tangga: Beragam Solusi Cerdas Konflik Keluarga Anda. Yogyakarta: Sampang, cet. I.

Batubara, M.U. et al. (2019). Islamic Communication Pattern of Judges in Dealing Conflict of Muslim Families in the Religious Court Medan. Budapest International Research and Critics Institute-Journal (BIRCI-Journal). P. 373-386.

Bhakti, Yayasan Panca Wira. (1996). Bunga Rampai: Perilaku Tentang Kriminalitas Remaja dan Pemuda Beserta Pembinaannya. Jakarta, t.p.

Candra, Mardi. Aspek Perlindungan Anak Indonesia: Analisis tentang Perkawinan di Bawah Umur. Jakarta: Prenadamedia Group, cet. I, 2018.

Departemen Agama R.I.(1997) Direktorat Jenderal Pembinaan Kelembagaan Agama Islam, Instruksi Presiden R.I. Nomor I Tahun 1991 Kompilasi Hukum Islam di Indonesia. Jakarta: Dir. Pembinaan Badan Peradilan Agama Islam.

Habīb, Sa īd Abū. (2011). Al-Qāmūs al-Fiqhi Lugatan wa Ișṭilāḥan. Damaskus: Dār Nūr aṣȘabāh, cet. I.

Hartanto, Andy.(2010) Hukum Harta Kekayaan Perkawinan Menurut Burgerlijk Wetboek dan Undang-Undang Perkawinan. Yogyakarya: Laksbang Pressindo, cet. III, 2017. 'Imarah, Muhammad. Haqāiq wa Syubhāt Ḥaula Makānati al-Mar'ati fi al-Islāmi, Kairo: Dārussalām, cet. I.

Imām Muḥammad bin Ismā' ̄̄l bin Șalāh al-Amīr aṣ-Ṣan ānī. (2007). Subul as-Salām Syarḥ Bulūg al-Marām min Jam i Adillati al-Aḥkām. Kairo: Syirkat al-Quds li an-Nasyr wa at-Tauzī', jilid III.

Ika."Harga Bahan Pokok Turun di Tengah Pandemi Covi-19, Sumut Berpotensi Deflai Maret," dalam suaratani.com. 
Ismail, Asep Usman.(2012). Al-Qur'an dan Kesejahteraan Sosial: Sebuah Rintisan Membangun Paradigma Sosial Islam yang Berkeadilan dan Berkesejahteraan. Tangerang: Lentera Hati, cet. I.

Jarādāt, Aḥmad `Ali. (2016). Al-Ijtihād al-Qaḍā’ī li Maḥkamah al-Isti’nāf asy-Syar`iyyah fi al-Aḥwāl asy-Syakhașiyyah fi Zilli Qānūn al-Aḥwāl asy-Syakhaṣiyyah al-Jadīd. Ammān: Dārun Nūr al-Mubīn, Jilid II, cet. I.

Judiasih, Sonny Dewi. (2018). Perkawinan Bawah Umur Di Indonesia Beserta Perbandingan Usia Perkawinan dan Praktik Perkawinan Bawah Umur di Beberapa Negara. Bandung: Refika Aditama, cet. I.

Latief, M. Nur Hasan. (2016). "Pembaharuan Hukum Keluarga Serta Dampaknya Terhadap Pembatasan Usia Minimal Kawin dan Peningkatan Status Wanita”, dalam Jurnal Hukum: Novelty, vol. 7, no. 2 Agustus.

Muntamah, Ana Latifatul. (2019)."Pernikahan Dini Di Indonesia: Faktor Dan Peran Pemerintah: Perspektif Penegakan Dan Perlindungan Hukum Bagi Anak," dalam Widya Yutika Jurnal Hukum, vol. 2, no. 1.

Nuruddin, Amiur. et. al., Ed. Muhammad Iqbal. (2008). Metolodologi Penelitian Ilmu Syari ah. Bandung: Ciptapustaka Media.

Noor, Juliansyah.(2013). Metodologi Penelitian: Skripsi, Tesis, Disertasi, dan Karya Ilmiah, cet. 3. Jakarta: Kencana.

Santrock, John W. (2007). Remaja. Jakarta: Erlangga, Edisi 11, Jilid 1.

Salim, Moh. Haitam. (2013). Pendidikan Agama dalam Keluarga: Revitalisasi Peran Keluarga Dalam Membangun Generasi Bangsa yang Berkarakter. Jogjakarta: Ar-Ruzz Media, cet. I.

Salinan Undang-Undang Republik Indonesia Nomor 16 Tahun 2019 Tentang Perubahan Atas Undang-Undang Nomor 1 Tahun 1974 Tentang Perkawinan.

Statistik, Badan Pusat. (2020). Pencegahan Perkawinan Anak: Percepatan yang Tidak Bisa Ditunda, tahun.

Syah, Ahmad Syahid. Pelaksanaan Pembayaran Nafkah `Iddah dan Mut ah Sebelum Ikrar Talak Perspektif Sadd Al-Dzari`ah. Studi di Pengadilan Agama Samarinda), dalam SAKINA: Journal of Family Studies, vol. 3, 2019.

Sikti, Ahmad Syahrus. (2019). Dinamika Hukum Islam, cet. 1. Yogyakarta: t.p.

Suyanto, Bagong. Masalah Sosial Anak. Jakarta: Kencana, cet. III, 2016.

Tarmizi, Kode Etik Profesi Tentang Hukum, cet. 1. Jakarta: Sinar Grafika, (2019).Tim Penyusun, Himpunan Perundang-Undangan Republik Indonesia:

Undang-Undang Perlindungan Anak. (2018). Jakarta: Laksana, cet. I,.https://www.mahkamahagung.go.id.

Binjai, Pengadilan Agama. (2017). Laporan Tahunan 2016. Binjai: 03 Januari.

Medan, Pengadilan Agama. (2017). Laporan Tahunan 2016. Medan: 04 Januari.

Stabat, Pengadilan Agama. Laporan Tahunan 2016. Binjai: 23 Desember 